\title{
A study of using solar energy to cure concrete bricks
}

\author{
Bach Dinh Thien and Hoang Vinh Long* \\ National University of Civil Engineering, Department of Building Materials, Hanoi, Vietnam
}

\begin{abstract}
Use of renewable energy sources such as solar energy, wind energy, tidal energy, etc. are important solutions in the trend for sustainable development. The purpose of this research is to build tunnels using solar energy to cure concrete bricks at saturated steam condition. Heat supply system and temperature monitoring of the tunnels consists of three main parts: solar thermal collector to heat water, heat trapping structure, and temperature measurement system with internet connection. The test operation of tunnels in industrial scale was conducted at a factory in Ho Chi Minh City. The results show that it can achieve temperatures above $50^{\circ} \mathrm{C}$ met curing requirements of concrete bricks. This can confirm the feasibility to use solar energy curing concrete bricks in plants with areas corresponding climatic conditions.
\end{abstract}

\section{Introduction}

Fired clay bricks are the traditional material used commonly in Vietnam. However, production of clay bricks requires consuming large amounts of clay and fuel that cause an adverse effect on the area of arable land and the environment. To solve this problem, in recent decades, Vietnam's Government has strengthened management in order to limit the production of clay bricks and develop unburned building materials. There are two important documents included the Decision-TTg dated 28/04/2010 567QD number of the Prime Minister on approving the Development program unburned building materials by the year 2020 and Decision No. 1469 / QD-TTg of the Prime Minister: To approve the master plan on development of Vietnam's construction materials up to 2020 and orientations to 2030. Accordingly, by the year 2020, Vietnam needs about 30 billion standard bricks. The amount of unburned materials will account for about $40 \%$ respectively 12 billion standard bricks, in which concrete bricks account for $70 \%$ of unburned materials.

In the production process of concrete bricks, steam curing stage is needed to develop strength fast, stable quality and shorten manufacturing process. According to many studies, temperatures of the curing is 50 to $100^{\circ} \mathrm{C}$ [1] and it need about $9-18 \mathrm{~h}$ in a condition of saturated steam curing to reach $70 \%$ of compressive strength at age of 28 days [2]. Steam supply source for the curing process is typically from boilers fired by fossil fuels. Disadvantages of boilers is demanding fuel costs, labour safety and environmental impact. To overcome this drawback, there have been studies using solar energy for curing process

\footnotetext{
* Corresponding author: longhv@ nuce.edu.vn
} 
with high efficiency. Podgornov N.I. [1] mentioned that curing temperature is higher $30^{\circ} \mathrm{C}$ than ambient temperature when using the structural solar collectors as shown on Fig. 1. After 3 days cured in tunnels using solar energy, compressive strength of concrete reach 70$80 \%$, and after 5-7 days' reach $100 \%$ that of the design strength.

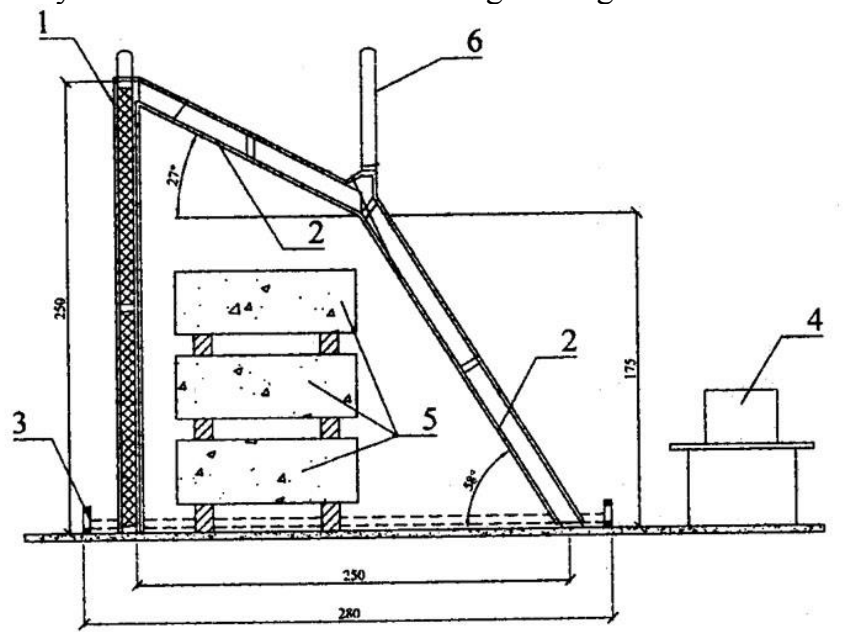

Fig. 1. Structure collecting solar energy to cure concrete structures

1- insulating wall; 2- , heat trapping structure; 3-water trough;

2- 4- control device; 5 - concrete structures; 6 - structure used when assembling.

A construction company in Qashqadaryo, Uzbekistan built curing tunnels in industrial scale collected solar energy. Concrete floors and walls of the tunnels with heat accumulating function from the sun's rays; and the roof of the tunnel with $30^{\circ}$ angle compared to the horizontal were made of two-glass layers with $30 \mathrm{~mm}$ of space between them. When the ambient temperature is $35-40^{\circ} \mathrm{C}$, temperature in the tunnels reaches 70 $80^{\circ} \mathrm{C}$. After cured 1 day, concrete structures achieve $45-50 \%$, and after 2 days of reaching $60-70 \%$ compressive strength of design. In Pennsylvania, the United States, several factories have used steam at a temperature of $180^{\circ} \mathrm{C}$ heated by solar energy to cure concrete structures. Thermal energy savings is up to $35 \%$ annually [1].

The Southern Vietnam is located in the area of tropical monsoons climate with high temperatures and rainy-dry seasons. Annual statistics [3] have shown that the average temperature in the Southern region is around $28.8^{\circ} \mathrm{C}$, the highest compared to that of the country. Temperatures between the months of the year is also very stable with high thermal radiation $5595 \mathrm{~W} / \mathrm{m}^{2} /$ day, and sunshine hours are $207 \mathrm{~h} / \mathrm{month}$. This is a good condition to be able to take advantage of solar energy for the curing process.

Currently, in Vietnam concrete brick factories has not really pay attention in the curing process. Each plant uses different curing processes such as wet spraying on 1-2 days, soaking in water, saturated steam maintenance with steam generated from boilers, etc. This is a cause of amount increases of used cement, unstable quality of products and large store area. Therefore, the purpose of this study is using solar energy to cure concrete bricks and apply in the Southern region of Vietnam. Based on the result of this research, applications of solar energy could be strengthened to implement that allow reduced fuel costs and $\mathrm{CO}_{2}$ emissions. 


\section{Materials and Methods}

This study was implemented in Dai Dung green materials joint stock company in Hiep Phuoc Industrial Zone, Hiep Phuoc, Nha Be District, Ho Chi Minh City. Concrete bricks with 4 round holes and dimension of $80 \times 80 \times 180 \mathrm{~mm}$ were used for tests. Mixture compositions to produce bricks are PC40 cement $200 \mathrm{~kg} / \mathrm{m}^{3}$, aggregate $1700 \mathrm{~kg} / \mathrm{m}^{3}$, fly ash $60 \mathrm{~kg} / \mathrm{m}^{3}$, and water $250 \mathrm{l} / \mathrm{m}^{3}$. Test method TCVN 6477: 2016 was use to determine the compressive strength of the two groups: samples 1 were cured in tunnels using solar energy, samples 2 were stored in indoor condition. The aim of tests is to determine influence of maintenance conditions on development of compressive strength.

Production process of concrete bricks using solar energy is basically the same the normal process from preparing to shaping steps. After being shaped, bricks are lined up racks, next kept in 10-12 hours in curing tunnels to reach strength of packaging, then wrapped plastic film up, and lastly stored in 10-14 days. The process of manufacturing concrete bricks is described in Fig. 2.

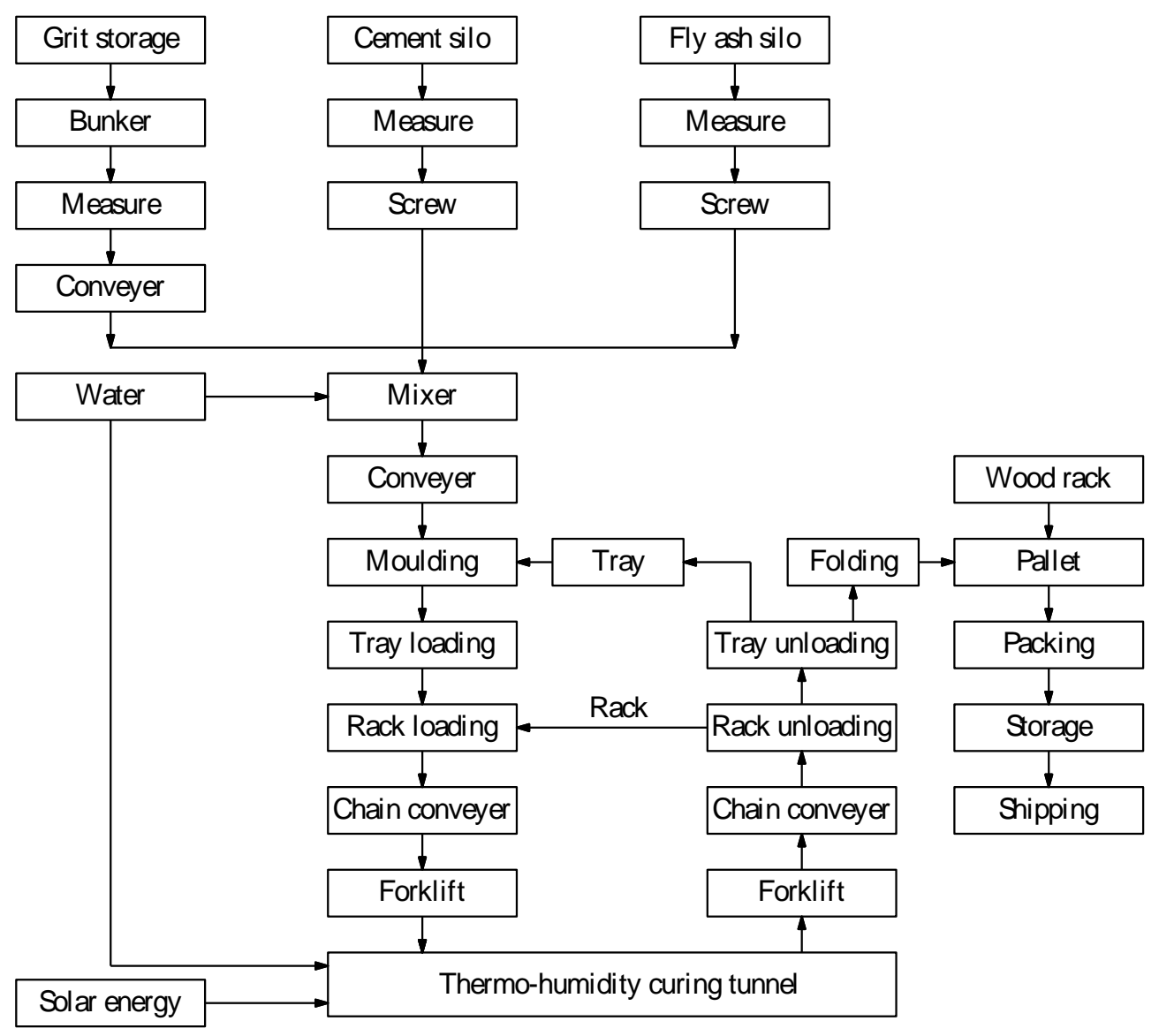

Fig. 2 Diagram of the line production technology of concrete bricks 


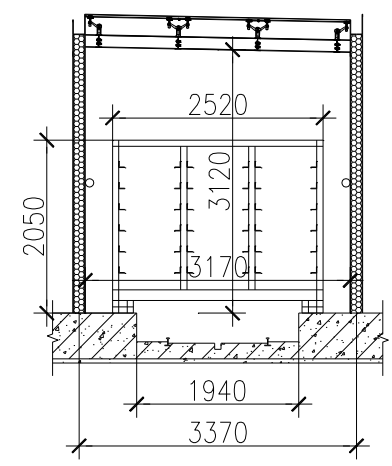

Fig. 3 Cross section of curing tunnel

After shaping, bricks were moved to the system of 7 curing tunnels using solar energy. The size of each tunnel is length $\mathrm{L}=24 \mathrm{~m}$, width $\mathrm{W}=3.17 \mathrm{~m}$ and height $\mathrm{H}=3.12 \mathrm{~m}$. The bottom of the tunnel is made from reinforced concrete with $0.25 \mathrm{~m}$ of thick, the walls is made from $100 \mathrm{~mm}$ thick layer of styrol concrete. The roof of the tunnel is made of two plates of tempered glass receiving sunlight, that is so called heat trapping structure to provide heat for the curing process (see Fig. 3).

Heat supply system and temperature monitoring of tunnels includes 3 main parts as following:

\subsection{Solar thermal collector}

Solar thermal collector of MGS VC-1850 heating water includes 10 panels with 500 $\mathrm{kg} /$ panels. Each panel is composed of two successive smaller plate with dimensions of 2000 x $4000 \mathrm{~mm}$ including 50 pipes of size $58 \times 1800 \mathrm{~mm}$. The panels are fixed to the roof of the factory. Cold water is supplied to the solar collector plates by a pipe with diameter of 50 $\mathrm{mm}$. Hot water goes out to a tank by a pipe with increased diameter of $32 \mathrm{~mm}, 40 \mathrm{~mm}$, and $50 \mathrm{~mm}$ (see Fig.4).

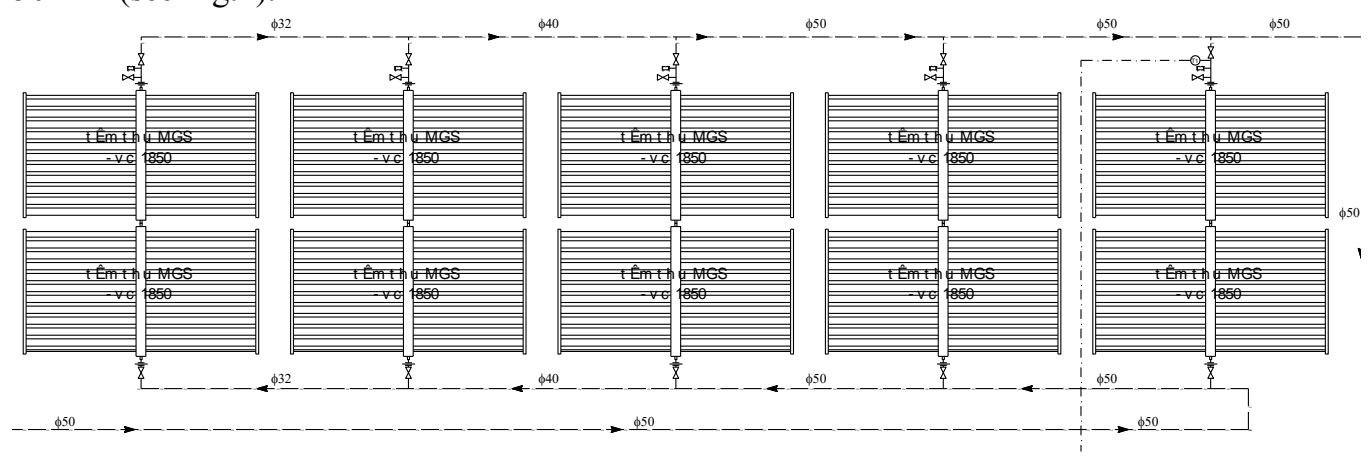

Fig. 4. Layout of solar panels heating water

\subsection{Heat trapping structure}

Heat trapping structure is made from 2 tempered glass plates with the distance between them is $20-25 \mathrm{~mm}$. The plates are sealed together with glue to make sure no air or moisture enters. The inclination of glass roofs is minimum of $2 \%$ that make rainwater and steam can not be deposited on the surface of glass. The gap between the two glass plates have the 
effect of retaining the energy reflecting back to the environment, therefore they are called heat trapping structure

\subsection{Temperature measurement system}

8 temperature sensors are installed for each curing tunnel in which the sensor \#1 measure temperature of heat water at sprinkler head spraying water, another one is used for waste water, 5 sensors show internal temperature of a tunnel and a sensor shows ambient temperature. Only with tunnel number 7, an outside sensor (\# 8) is used for measuring the hot water temperature in a tank. The signal of all these sensors are transmitted from a transceiver to a GPS system. Then, the data is shown on the monitor via the internet. Thus, we can check temperature anywhere and at any time. The temperature measurement system using the type of DS18B20 sensors with error less than $0.5^{\circ} \mathrm{C}$, and measure range of $-55^{\circ} \mathrm{C}$ to $+125^{\circ} \mathrm{C}$.

\section{Results and Discussion}

\subsection{Temperature measurement results in the curing tunnels [4]}

Temperature measurement results on a monitor could be get as shown in Fig. 5.

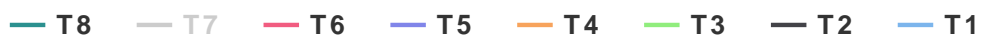

$$
\begin{aligned}
& \text { From Apr 20,2018 To Apr 21, } 2018
\end{aligned}
$$
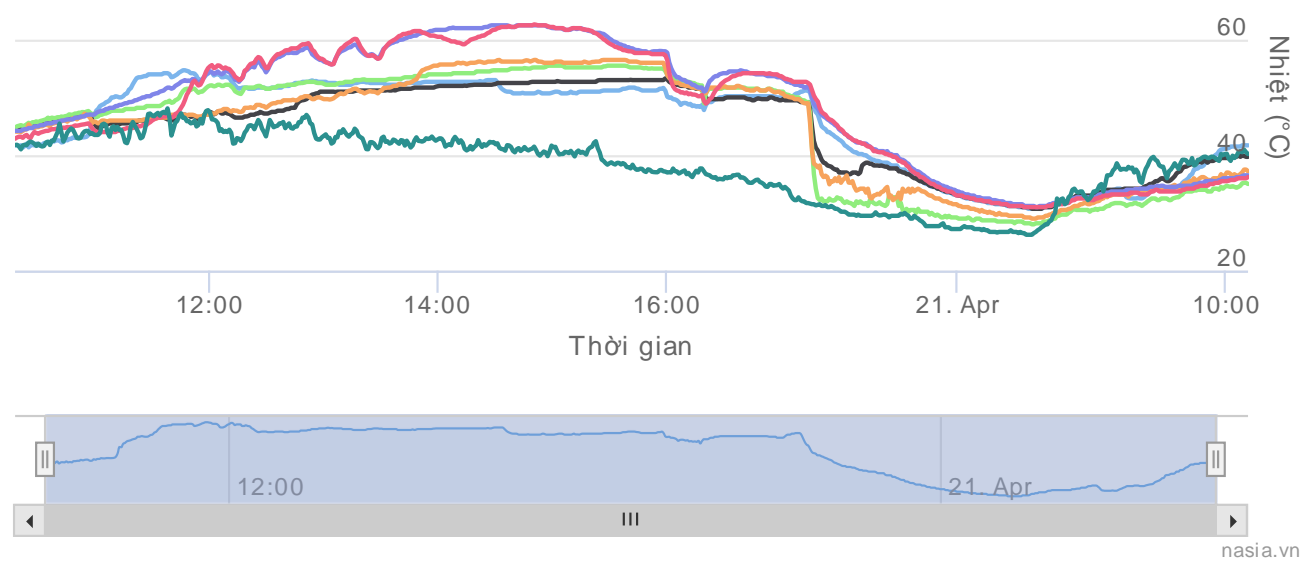

Fig 5. Temperature chart of the tunnel \#7 on April 20, 2018

The tunnels should continuous work with the entire production process of the factory. Therefore a operation plan of the 7 tunnels was designed as Table 1. 
Table 1. An operated plan of the 7 curing tunnels on a day

\begin{tabular}{|l|l|l|l|l|l|l|l|l|l|l|l|l|l|l|l|l|l|l|l|l|l|l|l|}
\hline $\begin{array}{l}\text { Num } \\
\text { ber } \\
\text { of } \\
\text { tun } \\
\text { el }\end{array}$ \\
\hline 1
\end{tabular}

Notation : A- Time to supply brick racks to a tunnel, $2 \mathrm{~h}$;

B- Time to stabilize bricks, $4 \mathrm{~h}$;

C- Time to cure bricks a tunnel, $8 \mathrm{~h}$;

D- Time of tempering and cooling bricks in tunnels, $8 \mathrm{~h}$;

E- Time of unloading bricks out of a tunnel, $2 \mathrm{~h}$;

The research team has conducted a test operation of the curing system using solar energy, and measured and analysised temperature data from June 5, 2018 to July 4, 2018 in the tunnels of over $50^{\circ} \mathrm{C}$. Temperature measurement results are listed in Table 2.

Table 2. Temperature measurement results in the 7 tunnels $\left({ }^{\circ} \mathrm{C}\right)$

\begin{tabular}{|c|c|c|c|c|c|c|c|}
\hline \multirow{2}{*}{ Date } & \multicolumn{7}{|c|}{ Number of tunnels } \\
\hline & 1 & 2 & 3 & 4 & 5 & 6 & 7 \\
\hline June 5 & & & & & & 52.6 & \\
\hline June 6 & 50.2 & & & 51.5 & & 52.6 & \\
\hline June 7 & & & 55.8 & 57.5 & 59.5 & & \\
\hline June 8 & & & 50.1 & 50.9 & & & \\
\hline June 9 & & 52.8 & 53.0 & & & & \\
\hline June 10 & & 56.6 & 57.1 & & & & 53.6 \\
\hline June 11 & & 51.4 & 53.5 & & & & \\
\hline June 12 & & 53.6 & & & & & \\
\hline June 13 & & & & & & & \\
\hline June 14 & & & 52.9 & & & & \\
\hline June 15 & & & 52.1 & 54.0 & & & \\
\hline June 16 & & & & & 52.8 & 54.4 & \\
\hline June 17 & & & & & & 52.8 & \\
\hline June 18 & & & & & 50.6 & & \\
\hline June 19 & 50.1 & 50.1 & & & 52.7 & & \\
\hline June 20 & & & & & & 57.4 & \\
\hline
\end{tabular}




\begin{tabular}{|c|c|c|c|c|c|c|c|}
\hline June 21 & & 51.1 & & & 52.7 & 56.5 & \\
\hline June 22 & & & & & & & \\
\hline June 23 & & & 50.2 & & & 58.1 & \\
\hline June 24 & & 51.3 & & & 53.4 & 52.1 & 50.0 \\
\hline June 25 & & & & & & 54.4 & \\
\hline June 26 & & 50.1 & & 50.5 & & 57.1 & \\
\hline June 27 & & 51.7 & 55.2 & 55.1 & & & \\
\hline June 28 & 55.3 & 60.5 & 58.5 & & & & \\
\hline June 29 & 57.4 & 56.2 & 53.6 & & 55.8 & 50.3 & \\
\hline June 30 & & & & & 57.6 & 57.2 & 51.2 \\
\hline July 1 & & & & 55.3 & 60.6 & & 51.6 \\
\hline July 2 & & & & & & & \\
\hline July 3 & & 53.7 & 51.7 & 52.7 & & & \\
\hline July 4 & 52.3 & & 50.8 & 52.1 & 53.2 & 54.6 & \\
\hline Sum & $\mathbf{5}$ & $\mathbf{1 2}$ & $\mathbf{1 3}$ & $\mathbf{9}$ & $\mathbf{1 0}$ & $\mathbf{1 3}$ & $\mathbf{4}$ \\
\hline
\end{tabular}

Temperature in curing tunnels was over $50^{\circ} \mathrm{C}$ in 26 days of the month trial operating. Averagely temperature of 2.54 tunnels was over $50^{\circ} \mathrm{C}$ per day, so the rate was $86.7 \%$ compared with sunny days. Because of trial operation, brick forming system did not work stably, therefore there were not many brick in the tunnels. That means heat of hydration of cement had not been taking full advantage, causing decrease of maximum temperature. The temperature is expectably higher when the entire production system of the factory stabilizes.

\subsection{Effect of curing regime on the development of brick strength}

To compare the effect of curing regime on the development of brick strength, brick samples were divided into 2 groups, namely: group 1 samples were taken at different position of brick racks, next cured in tunnels in 1 day, then stored in a room condition; immediately after forming, group 2 samples were covered/ not covered by plastic film, then stored in room condition. Results of compressive strength test are given in Table 3.

Table 3. Compressive strength of concrete brick samples

\begin{tabular}{|c|c|c|c|c|c|c|c|}
\hline \multicolumn{3}{|c|}{ Curing condition } & \multicolumn{5}{|c|}{ Compressive strength of concrete brick samples, MPa/\% } \\
\hline & $\begin{array}{l}\text { Number } \\
\text { of tunnel }\end{array}$ & $\begin{array}{l}\text { Position } \\
\text { of bricks }\end{array}$ & $f_{c}^{1 d a y}$ & $f_{c}^{3 \text { days }}$ & $f_{c}^{7 \text { days }}$ & $f_{c}^{14 \text { days }}$ & $f_{c}^{28 \text { days }}$ \\
\hline \multirow{6}{*}{$\begin{array}{l}\text { Curing } \\
\text { in } \\
\text { tunnels }\end{array}$} & \multirow{3}{*}{ Số 2} & Side & $5.83 / 40.5$ & $7.59 / 52.7$ & $12.70 / 88.2$ & $13.15 / 91.3$ & $14.4 / 100$ \\
\hline & & Center & $5.16 / 34.6$ & $7.06 / 47.3$ & $11.62 / 77.9$ & $14.10 / 94.6$ & $14.9 / 100$ \\
\hline & & Top & $5.24 / 50.3$ & $6.83 / 65.6$ & $6.92 / 66.5$ & $8.26 / 79.4$ & $10.4 / 100$ \\
\hline & \multirow{3}{*}{ Số 3} & Side & $4.79 / 42.3$ & $6,60 / 58.4$ & $7.56 / 66.9$ & $10.60 / 93.8$ & $11.3 / 100$ \\
\hline & & Center & $5.25 / 44.1$ & $7,33 / 61.6$ & $9.0 / 75.6$ & $10.50 / 88.2$ & $11.9 / 100$ \\
\hline & & Top & $5.07 / 43.2$ & $7.10 / 60.5$ & $7.4 / 63.9$ & $8.50 / 72.4$ & $11.7 / 100$ \\
\hline \multirow[t]{2}{*}{$\begin{array}{l}\text { Store in } \\
\text { room }\end{array}$} & $\begin{array}{c}\text { Not } \\
\text { covered }\end{array}$ & & $3.23 / 28.8$ & $4.74 / 42.3$ & - & - & $11.2 / 100$ \\
\hline & Covered & & $3.44 / 26.8$ & $5.26 / 41.1$ & - & - & $12.8 / 100$ \\
\hline
\end{tabular}


Note: data are presented in the form of fractions $\mathrm{A} / \mathrm{B}$ in which $\mathrm{A}$ is compressive strength at respective age ( $\mathrm{MPa}$ ), $\mathrm{B}$ is the compressive strength ratio between the age and $\mathrm{B}$ is the ratio of compressive strength at age respectively compared to 28 days (\%)

The results in Table 3 show that there is the difference in the development of compressive strength. However, strength of group 1 samples after 1-day cured in the tunnels was averagely $42.5 \%$ compared to that at 28 days; strength of group 2 samples was $27.7 \%$ respectively.

\subsection{Evaluate the effectiveness of energy, environment and investment}

According to calculations, curing by solar energy will shorten the time taken to use the concrete bricks as shown in Table 4. Moreover, the number of pallets is reduced to $1 / 3$, area storing products lessen $30-40 \%$.

Table 4. Calculating effect on time of curing by solar energy

\begin{tabular}{|c|c|c|}
\hline & $\begin{array}{c}\text { Curing by using solar } \\
\text { energy }\end{array}$ & Moist curing \\
\hline Time to exworks & $3-5$ days & 21 days \\
\hline Time to use & $10-14$ days & 28 days \\
\hline
\end{tabular}

Based on operation results of the 7 tunnels, fuel cost for curing was calculated when reaching design capacity of 37 million standard bricks/ year of a production chain. Namely, 5.3 ton of coal or 3.2 ton of FO oil is need for curing by boilers. Investment costs for the entire curing system would be 2.4 billion VND. As a result, it is needed 4 years for capital recovery. Furthermore, the use of solar energy for curing would cut $\mathrm{CO}_{2}$ emissions by 2.2 million $\mathrm{m}^{3} /$ year and 1.7 million $\mathrm{m}^{3} /$ year in cases of coal and $\mathrm{FO}$ oil respectively.

\section{Conclusions}

Based on the results of installing, operating and measuring temperature the curing tunnels using solar energy in Dai Dung green materials joint stock company, some conclusions could be drawn as following:

- Solution of using solar energy to cure concrete brick in the Southern region is workable with the rate of the highest temperature reaching above $50^{\circ} \mathrm{C}$ is $86.7 \%$.

- Curing by using solar energy promotes development of concrete brick strength. Namely after 1-day curing, compressive strength of brick samples achieved $42.5 \%$ of that at 28 days higher than that of the control sample at $27.7 \%$ respectively.

- At capacity of 37 million standard bricks/ year, curing by using solar energy saves 5.3 ton of coal or 3.2 ton of $\mathrm{FO}$ oil and cut $\mathrm{CO}_{2}$ emissions by 2.2 million $\mathrm{m}^{3} /$ year and 1.7 million $\mathrm{m}^{3}$ / year respectively compared to curing by boilers.

Many thanks to Project Management Unit "Promotion of non-fired bricks production and utilization in Vietnam" for facilitating the implementation of this study with Dai Dung green materirals joint stock company.

\section{References}

1. N.I. Podgornov, Heat treatment of concrete using solar energy. ASV, 328 p. (2010) 
2. Bazhenov Iu. M., B.D. Thien, T.N. Tinh, Concrete technology, Publisher Building, Hanoi, 494 pages (2004)

3. TCVN 4088:1985, Climate data used in building design, 205 pages.

4. B.D. Thien, H.V. Long, N.D. Binh, Final Report of Contract No: 2505/2018-HDTV-ĐT "Transfer cure technology using solar energy for Dai Dung green materirals joint stock company in Hochiminh city". Project Management Unit "Promotion of non-fired bricks production and utilization in Vietnam", UNDP, (2018) 